\title{
Cyberbullying: Psychological Effect on Children
}

\author{
Dr. Aarti Tolia ${ }^{1 *}$
}

\section{ABSTRACT}

The phenomenon of bullying is highly complicated. Bullying has been deep-rooted in Indian society since ages through the mythological periods of Mahabharata. Bullying has impaired various facets in the society including individual characteristics, peer, family relationships and dynamics and has led to lacerate community values, moral attitudes, resulting in stigma, discrimination and vulnerability. Technology has made this issue more obvious and aggravated with new forms of bullying such as cyber bullying with unique approaches to harass and intimidate peers for reasons unlimited such as -harassing by posting hurtful messages with or without mensrea, may be for good, bad, revenge, time pass or as an easy prank without understanding the menace they are inviting. Cyber bullying may be done by those who have to struggle with social, emotional or academic difficulties, bullying is not considered to be part of crime as often bullying is considered as a pre-requisite mischief in the developing stage of children hence involving in cyber bullying as victim or as the aggressor, maygo unrecognized by parents, teachers, children and teens. In this paper, I have aimed to explore the psychological aftereffect on children and teens after being constantly harassed on social media and critically framing it as "cyber-tort." The present paper attempts to integrate existing dilemma due to cyberbullying, and the omnipresent personality traits in online environment and deduce it to the psychological context.

Keywords: Bullying, Cyberbullying, Social Networking Sites, Psychology

The term bullying has its superfluous since ages. The word "bully" can be traced back as far as the 1530s.(Harper, 2008). Bullying involves two people, the bully and the bullied i.e. the intimidator and the victim. An added ingredient of technology has given an overall interpretation to the bullying mischief coined as cyber-bullying. Technology has connected the world with equivalent speed of thoughts with that of communication, thereby making it easy for conflicts to get into action faster via media such as the internet and telecommunication technology, introducing a new form of onslaught called cyber bullying.

\footnotetext{
${ }^{1}$ B.COM. M.A., LL.M., PhD (through National Law School of India University) Practicing law and Professor of Law (Mumbai)

*Responding Author

(C) 2016 I A Tolia; licensee IJIP. This is an Open Access Research distributed under the terms of the Creative Commons Attribution License (http://creativecommons.org/licenses/by/2.0), which permits unrestricted use, distribution, and reproduction in any Medium, provided the original work is properly cited.
} 


\section{Cyberbullying: Psychological Effect on Children}

The struggle to seek attention and acquire superiority over others has led to hostile antagonism and attracted superfluous competitions. As per the National Center for Educational Statistics one out of three students is bullied during the school year, another survey conducted by Sameer Hinduja and Justin W. Patchin (2015) states that 34\% students experienced cyberbullying from the total number of children surveyed, and adolescent girls are significantly more likely victims of cyberbullying in their lifetimes (40.6\% vs. 28.2\%). Cyberbullying is harassing the victim by various means such as verbal or physical aggression, assaulting face-to-face or even spreading online rum ours about the victim may be intentional and repeated bullying

Intentional repeated online harassment is carried on social networking sites by sending offensive emails, blogs and text messaging, commenting on social networking sites on others' profiles, and posting hateful and hurtful messages. The victim of cyberbullying undergoes a difficult phase in the real world due to the bullying carried on in virtual space resulting in irreparable psychological traumas. Only those who had undergone bullying can understand the trauma caused by it.

\section{PSYCHOLOGICAL EFFECT}

Cyberbullying psychological effects may not be noticed initially but the negative stress factors builds up overtime. Negative socializing through social networking sites has risk with after effects on children's future as well as during and after being bullied and increases the risk of developing number of health and psychological problems. ${ }^{2}$ Such after effects of being bullied on social networking sites may create emotional distress after or during using the internet, the child may stop socializing with friends and family and cut off himself from group gathering and often skip school with a considerable change in mood, sleep and appetite, the grades may fall and the child may become aggressive at home for no big reason.

Other after effects like great risk of anxiety, depression and stress related disorders, academic difficulties, aggressive behavior in class and family, alcohol or other drug abuse without the knowledge of parents, anxiety, attention \& retention problems, bad dreams or bed wetting, chronic pain, concentration problems, dangerous behavior such as speeding, dehydration, depression, dissociative states, eating disorders, failure to thrive, compare with others or evaluate own worth in the peer group, fear or shyness of certain adults or places. ${ }^{3}$

Sometimes the bullying tends the victim to suicide due to pressure, embarrassment and with a feeling that he/she has no other alternatives. Unmonitored use of technology aids to plenty of room for malicious online activities.

The social networking sites like Facebook may cause 'Facebook Depression' a term framed by the American Academy of Paediatrics resulting in a feeling of unpopularity or excluded from the

\footnotetext{
${ }^{2}$ findcounseling.com, http://www.findcounseling.com/journal/child-abuse/child-abuse-effects.html accessed on 29/3/2014.

${ }^{3}$ Ibid
} 


\section{Cyberbullying: Psychological Effect on Children}

events or group when children see updated status or photos on Facebook. ${ }^{4}$ Acceptance by and contact with peers ${ }^{5}$ is an crucial aspect of adolescence life, with the offline depression, children and adolescence who suffer from Facebook Depression may feel social isolation and sometimes such bullied children while in search of relief opt to look into websites and blogs which have abusive content, encourage for sexual activities and may motivate to self-harm or aggressive behavior. ${ }^{6}$

A survey conducted by of the Cyber-bullying Research Center reported 8\% from the total surveyed accepted that they have been bullied to an extent that preferred and attempted to suicide, run away, declined going to school and/or have become chronically ill. Another research said that 38\% cyberbully victims felt hostile, 37\% annoyed whereas $24 \%$ defenseless. It has also been noticed that majority girls were frustrated and angry compared to boys (Johnson Institute, 1994) Sandra Williams, 2007, in her explanation on the aftereffect of being bullied stresses on how painful it is for teens to face public humiliation as this online violence is a complex issue with many and varied causes and consequences.

Dr. Randy A. Sansone, a professor in the Departments of Psychiatry and Internal Medicine at Wright State University in Dayton, Ohio, concedes on the ramification of bullying as- "In the aftermath of being bullied, victims may develop a variety of psychological as well as somatic symptoms, some of which may persist into adulthood." ${ }^{7}$ Such psychological effects last for long and sometimes forever and leave troublesome reminiscence on the bully victim resulting in the light of the recent increasing school shootings. Hence bullying online or offline should not be overlooked as innocent mischief but need to be handled in time without ignoring the painful impact.

\section{SOCIAL PROBLEMS}

Cell phones with 24x7 internet access ease the process of stalking anytime-anyplace, stalking' by texting has become a pervasive problem. Bullying is more aggressive in the pre-teens when adolescents are on verge of figuring out how to develop personal relationships with peers, resulting in positive or negative lifelong ramification on an child victim's ability to manacle with others. Bullying knits a vicious cycle for the cyberbully victim. When the problem and discomfort of the child comes to knowledge of the parents, often parents prefer to turn to medications but this would only soothe the physical ailment leaving unsolved the emotional cause of the issue. Moreover if the victim does not get support from parents, teachers and schools, the already ongoing cyberbullying can worsen the situation.

\footnotetext{
${ }^{4}$ How Social Networks affect underage kids, see - http://everydaylife.globalpost.com/social-networks-affectunderage-kids-11322.html, accessed on 28/3/2014.

${ }^{5}$ S. V. Kale, Child Psychology and Child Guidance,HimalayaPublishin House, 2005, page 103.

${ }^{6}$ Mrs. Cohen's Research www.beavercreek.k12.oh.us/.../social\%20media\%20impact\%20on\%20te.accessed on 19/3/2014.

${ }^{7}$ The Psychological Effects of Bullying, - http://nobullying.com/the-psychological-effects-of-bullying/
} 


\section{CONCLUSION}

Cyberbullying has countless aftereffects but the most destructive are the emotional and psychological effects, which are not limited to hurt feelings that should be easily despised. Many adolescents may carry a lifelong catastrophic that damages the psyche. The very first symptom of cyberbullying victim child may reflect through change in his/her emotions and behaviour pattern which should not go unnoticed to parents and school teacher and as such together the victim child, parents and psychology practitioners need to work to control the situations in time before it intensifies. The modern technology with cheap and easy available internet on almost all mini and macro devices makes cyber bullying relentless resulting in tragic actions like suicide and self-harm and apparently more needs to be done in order to protect vulnerable victims of online bullying.

\section{REFERENCES}

1) NoBullying.com,-http://nobullying.com/the-psychological-effects-of-bullying/

2) UB University Business,-http://www.universitybusiness.com/article/psychologicalimpact-cyber-bullying

3) AOA,-http://www.osteopathic.org/osteopathic-health/about-your-health/healthconditions-library/general-health/Pages/cyber-bullying.aspx

4) Cyberbullying and its impact on young people's emotional health and well-being, http://pb.rcpsych.org/content/37/5/167

5) Cyber-bullying Research Center, - http://cyberbullying.org/about-us/

6) PewReseachCenter, http://www.pewinternet.org/2007/06/27/cyberbullying/?beta=true\&utm_expid=53098246 -2.Lly4CFSVQG2lphsg-KopIg.1\&utm_referrer=https\%3A\%2F\%2Fwww.google.com 